\title{
Esophageal dysphagia pada kucing ras lokal
}

\author{
Arief P. Mihardi ${ }^{1} *$, Malni Sovinar ${ }^{2}$, Dinda Septina Br Tampubolon ${ }^{2}$ \\ ${ }^{1}$ Departemen Klinik Reproduksi dan Patologi, Fakultas Kedokteran Hewan, Institut Pertanian Bogor, Bogor. \\ ${ }^{2}$ Dokter Hewan Praktisi, Bobon and Vet, Bogor
}

\begin{abstract}
ABSTRAK: Dysphagia merupakan suatu manifestasi gangguan pada esofagus. Beberapa gangguan pada esofagus yang menunjukkan gejala dysphagia yaitu esophageal stricture. Tulisan ini mengevaluasi kausa gejala esophageal dysphagia pada kucing Tripod. Seekor kucing ras lokal bernama Tripod dibawa ke klinik oleh pemiliknya dengan keluhan adanya kepincangan dan luka pada kaki kanan depan. Tripod menunjukkan gejala muntah setiap kali diberi pakan pascaamputasi. Hasil pemeriksaan fisik tampak adanya massa pada leher Tripod saat diberi pakan. Citra radiografi dengan kontras barium sulfat menunjukkan adanya penyempitan pada bagian esofagus dan anterior lambung. Kucing Tripod didiagnosa mengalami esophageal dysphagia. Terapi yang diberikan tindakan suportif dengan pemberian multivitamin dan pakan yang semi cair.
\end{abstract}

Kata kunci:

dysphagia, esofagus, kucing, muntah, radiografi

\section{- PENDAHULUAN}

Esofagus merupakan otot yang berbentuk tubular yang berfungsi untuk mengantarkan makanan dari faring menuju ke lambung. Saat kondisi relaksasi, esofagus akan kolaps, namun esofagus mampu menggembung kembali untuk mengantarkan cairan maupun makanan (Tams 2003). Adanya gangguan pada daerah esofagus menyebabkan makanan tidak dapat menuju lambung, seperti kondisi dysphagia.

Dysphagia merupakan gejala klinis umum berupa kesulitan dalam menelan makanan di sepanjang saluran pencernaan atas (Ettinger et al. 2017). Dysphagia dibagi menjadi oral dysphagia, pharingeal dysphagia, cricopharingeal dysphagia, esophageal dysphagia dan gastroesophageal dysphagia. Oral dysphagia mengacu pada kesulitan dalam prehensi pakan. Pasien dengan kejadian pharingeal dysphagia tidak ada kelainan dalam prehensi pakan namun gagal menuju ke kerongkongan. Hewan yang mengalami pharingeal dysphagia akan menunjukkan gejala muntah. Pasien dengan kondisi cricopharingeal dysphagia menunjukkan prehensi yang normal namun tidak dapat menelan dengan sempurna.

Kasus esophageal dysphagia cenderung mengalami kesulitan dalam menghantarkan pakan dari esofagus ke lambung (Pollard 2012). Tulisan ini mengevaluasi secara klinis dan pemeriksaan penunjang pada kucing ras lokal yang menunjukkan gejala dysphagia.

\section{- KASUS}

Sinyalemen: Kucing dengan ras lokal bernama Tripod berjenis kelamin betina dan rambut berwarna putih - belang (Gambar 1A). Anamnesa: Pemilik membawa kucing ke klinik dengan keluhan ada luka dan kepincangan pada kaki kanan depan. Kucing merupakan kucing liar yang dibawa dari pasar. Setelah dilakukan tindakan amputasi dan dilakukan rawat inap, Tripod selalu memuntahkan makanan sesaat setelah diberi pakan. Gejala klinis: Memuntahkan pakan, adanya pembesaran pada daerah leher sesaat setelah diberi pakan, saat dilakukan palpasi ada masa pada daerah leher. Pemeriksaan penunjang: Radiografi dengan bahan kontras barium sulfat ditemukan adanya penyempitan lumen esofagus dan anterior lambung (Gambar 1B). Diagnosa: esophageal dysphagia. Prognosa: Dubius - Fausta.

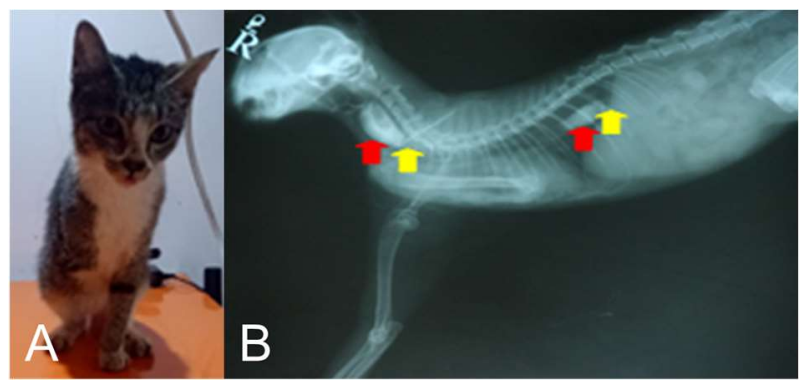

Gambar 1. kucing Tripod pasca amputasi (A) dan radiogram dengan bahan kontras barium sulfat, sisa bahan kontras dan makanan (anak panah merah), adanya penyempitan esofagus (anak panah kuning).

\section{- HASIL DAN PEMBAHASAN}

Dysphagia merupakan simptom kesulitan dalam menelan. Kondisi abnormal dalam menelan tersebut dapat dibagi menjadi beberapa yaitu pada bagian oral yaitu pharyngeal dan

Diterima: 11-06-2021 | Direvisi: 19-07-2021 | Disetujui: 23-07-2021 (C) 2021 CC-BY-SA. Ini adalah artikel Open Access yang didistribusikan berdasarkan ketentuan dari Creative Commons Attribution ShareAlike 4.0 International License (https://creativecommons.org/licenses/by-sa/4.0/). 
cricopharyngeal (Hitt 2008) juga terjadi pada bagian esophageal dan gastroesophageal (Pollard 2012).

Kucing Tripod diantar ke klinik HPC Bekasi dengan keluhan adanya kepincangan dan luka terbuka pada kaki kanan depan (Gambar 1A). Setelah dilakukan pemeriksaan fisik, ditemukan adanya krepitasi pada kaki kanan depan dan tampak luka yang sudah membusuk pada kaki. Selanjutnya Tripod dilakukan tindakan amputasi.

Pasca operasi (kurang lebih 7 hari), Tripod menunjukkan gejala muntah sesaat setelah diberi pakan dan kejadian tersebut selalu berulang. Hasil pemeriksaan fisik, leher Tripod menunjukkan adanya benjolan dan massa juga sesaat setelah diberikan pakan. Sehinga Tripod disarankan dilakukan pemeriksaan penunjang radiografi (X-ray) dengan bahan kontras barium sulfat.

Hasil X-ray Tripod menunjukkan adanya sisa bahan kontras pada bagian faring dan esofagus. Selain itu juga menunjukkan adanya penyempitan lumen esofagus dan anterior lambung. Gambar x-ray dengan bahan kontras barium sulfat disajikan pada Gambar 1B. Hasil pemeriksaan penunjang tersebut Tripod didiagnosa mengalami esophageal dysphagia.

Esophageal dysphagia merupakan kesulitan dalam menghantarkan bolus pakan dari esofagus menuju lambung. Beberapa kausa yang dapat menimbulkan esophageal dysphagia diantaranya adanya massa pada esofagus/benda asing, striktur pada esofagus, kompresi ektraluminal esofagus (seperti pada kondisi kardiomegali, massa pada mediastinal, vascular ring yang abnormal), esofagitis serta megaesofagus (Marks 2008, Pollard 2012).

Kejadian esophageal dysphagia pada Tripod diduga akibat adanya striktur pada esofagus. Menurut Parnell (2008), striktur esofagus merupakan bekas luka yang berbentuk sirkular pada jaringan esofagus yang dapat menimbulkan penyempitan. Hasil studi Levine et al. (2014) dengan menggunakan video flouroscopic pada 11 ekor kucing yang mengalami $d y s$ phagia, menunjukkan bahwa esophageal dysphagia lebih sering terjadi karena hiatal hernia (5 ekor) dan striktur pada esofagus (3 ekor).

Menurut Tams (2003), kejadian striktur pada esofagus dapat terjadi karena esofagositis parah yang menyebabkan kerusakan pada lapisan dalam esofagus, sehingga memicu terjadinya proliferasi jaringan fibroblas. Esofagitis pada kucing dan anjing seringkali disebabkan adanya refluks asam lambung dan enzim pencernaan selama penggunaan anastesi umum, muntah yang persisten terutama pada pasien yang kondisinya lemah, obat (seperti NSAID), memakan pakan yang sifatnya asam, benda asing dan luka bakar. Kejadian striktur esofagus pada kasus Tripod diduga karena adanya gastroesophageal reflux (GER) pasca anastesi umum pada saat dilakukan tindakan amputasi. Sejalan dengan hasil studi Garcia et al. (2017) menunjukkan, 9 dari 27 kucing (33,3\%) mengalami GER pasca dilakukan anastesi umum.

Terapi yang diberikan untuk Tripod yaitu berupa pemberian pakan yang semi cair hingga saat ini. Menurut Parnell (2008), terapi yang dapat dilakukan pada kasus esofagus yang mengalami stiktur diantaranya menggunakan kateter balon maupun tindakan bedah dengan melakukan resection. Namun tindakan bedah tersebut memiliki tingkat keberhasilan yang lebih kecil dibandingkan dengan menggunakan kateter balon. Hasil studi Tan et al. (2018) menunjukkan tindakan terapi menggunakan teknik balloon dilatation esophagostomy relatif lebih baik dan efektif dalam mempertahankan dilatasi pada kasus striktur esofagus.

\section{SIMPULAN}

Berdasarkan hasil pemeriksaan fisik dan radiografi, kucing Tripod mengalami esophageal dysphagia. Kausa kejadian tersebut diduga adanya striktur pada esofagus. Terapi yang dilakukan pada Tripod yaitu terapi suportif dengan pemberian pakan yang semi cair.

\section{n INFORMASI PENULIS}

Penulis Korespondensi

* AP: mihardi.ap@apps.ipb.ac.id

Divisi Penyakit Dalam, Wing 2, Level 3

Departemen Klinik, Reproduksi dan Patologi,

Fakultas Kedokteran Hewan, Institut Pertanian Bogor, Bogor Jalan Agatis, Kampus IPB Dramaga Bogor 16680.

\section{- UCAPAN TERIMA KASIH}

Terima kasih kepada segenap staf Bobon and Vet, Bogor, sebagai tempat untuk mengkaji kasus ini sebagai bahan tulisan.

\section{- PUSTAKA ACUAN}

Ettinger SJ, Feldman EC, Côté E. 2017. Textbook of Veterinary Internal Medicine: Diseases of the Dog and the Cat. Ed ke-8. Volumes 2. Missouri: Elsevier.

Garcia RS, Belafsky PC, Maggiore AD, Osborn JM, Pypendop BH, Pierce T, Walker VJ, Fulton A, Marks SL. 2017. Prevalence of gastroesophageal reflux in cats during anesthesia and effect of omeprazole on gastic $\mathrm{pH}$. Journal of Veterinary Internal Medicine. 31(3): 734-742

Hitt ME. 2008. Pharyngeal and swallowing disorder. Di dalam: Morgan RV, editor. Handbook of Small Animal Practice. Ed ke-5. Missouri: Elsevier.

Levine JS, Pollard RE, Marks SL. 2014. Contrast videofluoroscopic assessment of dysphagic cats. Veterinary Radiology \& Ultrasound. 55(5): $465-471$

Marks SL. 2008. Dysphagia and Regurgitation in Dogs - More Common Than You Think. https:/www.vin.com/apputil/content/ defaultadv1.aspx?id=3866144\&pid=11258. [31 Oktober 2020].

Parnell NK. 2008. Esophageal disease. Di dalam: Morgan RV, editor. Handbook of Small Animal Practice. Ed ke-5. Missouri: Elsevier

Pollard RE. 2012. Imaging evaluation of dogs and cats with dysphagia. International Scholarly Research Notices. 2012: 1-15.

Tams TR. 2003. Disease of the esophagus. Di dalam: Tams TR, editor. Handbook of Small Animal Gastroenterology. Ed ke-2. Missouri: Elsevier.

Tan DK, Weisse C, Berent A, Lamb KE. 2018. Prospective evaluation of an indwelling esophageal ballon dilatation feeding tube for treatment of benign esophageal strictures in dogs and cats. Journal of Veterinary Internal Medicine. 32(2): 693-700. 